\title{
STUDY OF EFFICIENCY AND INFORMATION TRANSMISSION FOR AGRICULTURAL FUTURES MARKETS: A COMPARATIVE ANALYSIS BETWEEN BUENOS AIRES AND CHICAGO USING MONTHLY AND DAILY DATA ${ }^{\circ}$
}

ESTUDIO DE LA EFICIENCIA Y LA TRANSMISIÓN DE INFORMACIÓN PARA MERCADOS DE FUTUROS AGRÍCOLAS: UN ANÁLISIS COMPARATIVO ENTRE BUENOS AIRES Y CHICAGO UTILIZANDO DATOS MENSUALES Y DIARIOS

\author{
Jeremías Lachman* \\ Pablo Jack*
}

enviado: 23 febrero 2017 - aceptado: 24 abril 2017

\begin{abstract}
This paper aims to study and compare the efficiency in futures markets for soybean crop between Buenos Aires (MATBA) and Chicago (CME-CBOT) for the years 1994 through 2015. There are numerous studies that analyze this phenomenon independently, but few of them have done a comparative analysis between markets. Therefore, the main objective of this research — in addition to individually analyzing the efficiency in futures market in each country — is to be able to detect the existence of a relationship between the two markets. In this article we show that, in addition for market efficiency in all cases, market efficiency in MatBa was

\footnotetext{
* IIEP-Baires (UBA-CONICET). Correos electrónicos: jeremiaslachman@gmail.com, pablo_ jack03@hotmail.com

This work is an improvement on previous versions that were presented at different national and international congresses and seminars. We appreciate all the comments received from diverse colleagues, close friends and family. In particular, we would like to mention $\mathrm{PhD}$. Heike Joebges from HTW-University for her support and guide throughout this work. This paper was winner of the scholarship sponsored by the Association Asociación Argentina de Economía Agraria and granted during the eighth edition of the Congreso Nacional de Estudiantes de Postgrado en Economía (CNEPE).

Lachman, J., \& Jack, P. (2017). Study of efficiency and information transmission for agricultural futures markets: a comparative analysis between Buenos Aires and Chicago using monthly and daily data· Estudios económicos, 34 (69), 3-23.
} 
derived from the efficiency in CME-CBOT. This means that relevant information is transmitted from the Chicago market to the one in Buenos Aires. By using a cointegration approach based on Johansen (1995) we estimated the models with monthly and daily data.

JEL Code: G14, C32, Q14.

Keywords: Efficient Market Hypothesis, Vector Error Correction Model, Agricultural Finance.

\section{Resumen}

El objetivo de este trabajo es estudiar y comparar la eficiencia en los mercados de futuros de la soja entre los mercados de Buenos Aires (MatBa) y Chicago (CMECBOT) para los años 1994 a 2015. Existen numerosos estudios que analizan este fenómeno de forma independiente, pero ninguno de ellos ha hecho un análisis comparativo entre estos dos países utilizando este cultivo específico. Por lo tanto, el objetivo principal de este trabajo, además de analizar individualmente la eficiencia en los mercados de futuros en cada país, es poder detectar la existencia de una relación entre los dos mercados. En este artículo se muestra que, además de ser verificada la eficiencia de mercado en todos los casos, se encontró que la eficiencia del mercado en MatBa se deriva de la eficiencia en el mercado de CMECBOT. Este resultado implica que existe información relevante que es transmitida desde el mercado de Chicago hacia el de Buenos Aires. Utilizando un enfoque de cointegración basado en Johansen (1995) estimamos los modelos con datos mensuales y diarios.

Código JEL: G14, C32, Q14.

Palabras clave: hipótesis de mercados eficientes, modelo de vectores de corrección de error, finanzas agrícolas.

\section{INTRODUCTION}

Agricultural futures market could be a useful tool for both farmers and traders. Risk transmission and price discovery are the two main functions of futures market. Considering the price discovery function, in efficient futures market prices express the agents formed opinions on future spot prices. Fama (1970) and Mckenzi and Holt (1998), defined future market efficiency as the degree of precision by which the spot price of a certain commodity — in our case soybean — is 
forecasted by the price of a futures contract. In this way, outputted prices from future markets are a useful instrument for all related agents and firms to the traded commodity. As a result of its importance, future market efficiency has been deeply researched by numerous authors during the past decades. In fact, the recently commodity price boom drive a new set of investigations of this topic.

By the contrary, the role played by the trading volumes on market efficiency has been briefly studied and with mixed results. The intuitive idea suggests that thin markets, with low trading volume, imply a relatively small quantity and quality of information, so the future market may not work in efficiency conditions and there would be lack of the price discovery function. The empirical works that have been done (Carter, 1989; Maynard et al, 2001; Yang et al, 2001) does not provide concluding results of how trading activity affects prices.

In this paper we study and compare the efficiency in futures market for soybean crop between the markets in Buenos Aires (MatBa) and Chicago (CMECBOT) for the years 1994 through 2015. There are numerous studies that analyze this phenomenon independently, but none of them have done a comparative analysis between these two countries. Therefore, the main objective and novelty of this research - in addition to individually analyzing the efficiency in future markets in each country - is to be able to detect the existence of a relationship between the two markets. In other words, the intention is to show whether the individual efficiency of any of these markets is linked to the efficiency of the other.

In the first place, efficiency in futures market for the selected cases will be based on the existence - or lack - of at least one cointegrating relationship between the price of futures contracts and the spot price, as has been done by numerous authors (Ali and Gupta, 2011; Delgado and Lema, 2001; Fama, 1970, 1987 and 1991; Mckenzie and Holt, 1998). In this way, we will be able to confirm that markets have operated under efficient conditions for the period analyzed if there is a cointegrating relationship between the price of futures contracts and spot price.

In the second place, a study will be done based on a cointegration approach in order to test whether there is a relationship between the efficiency in futures markets in Buenos Aires (Argentina) and Chicago (The United States). Since the futures market in Buenos Aires has a significantly lower volume of operations than Chicago, a situation that can lead to market inefficiencies, the intention is to see if the price changes of the second determine the first. Thus, relevant market information is transmitted from one case to another, allowing for efficient markets to exist 
despite low trading volume ${ }^{1}$. This exercise was done firstly with monthly average data and secondly with daily data as a robust check.

In this paper we have two working hypotheses:

- Both futures markets for the selected crops, within the time period considered, operated efficiently. This is verified by the presence of at least one cointegrating relationship between the series of spot prices and futures contracts.

- There is a link between the futures markets of Buenos Aires and Chicago, which has been established through a cointegrating relationship between price series of contracts for each market, with each crop. If this relationship exists, it should be given greater influence in the Chicago market over the Buenos Aires market. This would imply that the price of contracts for the Chicago futures market is weakly exogenous in the cointegration relationship. This preposition should persist to the monthly average data and to the daily data.

Through this analysis we show in the first place, that both individual markets have been working in efficient conditions by the period considered, so future markets prices for soybean may have been a useful tool to forecast spot prices. In this way, we demonstrate that markets had been operating under conditions in which available information for all the agents is sufficient so that there are no individual gains or losses over time. In this sense, the empirical evidence confirms that, in a long run, prices at which the future contracts were traded had reflected spot prices.

In the second place, we proved that the efficiency in a futures market - the case of MatBa - derives from the efficiency in the other - CME-CBOT. In this way, we show evidence of how both markets interact so that the efficiency in one leads to efficiency in the other.

The paper is organized as follow: in the next section we present the literature review. In the second section we present the methodology, data used in the paper and the results of the unit root test. The main results are presented in the third section and at last the conclusions.

1 The annually traded volume in futures agricultural markets in Argentina represent a third of the total harvest, while in the United States this number is about eighty times the harvest. 


\section{LITERATURE REVIEW}

There is a vast amount of literature that addresses, through a cointegration approach, the study of efficiency in commodity futures markets and the existing relationship between trade volume and price volatility - in the cases of the works mentioned below. However, nothing was found that directly links both analytical schemes together.

Kumar and Sunil (2004) studied the efficiency of futures market for diverse commodities in India, concluding that futures prices are not a good indicator of the expected spot price. In the same line Wang and Ke (2005) researched the efficiency for wheat and soybean crops in China, finding a long-term balance between the price of the futures contracts and the spot price of soybean, but no such balance was found with wheat. The work done by Watkins and McAleer (2006), found a cointegrating relationship between the future price, the spot price, stock level and the interest rate for multiple metal commodities. In this same way, Mckenzie and Holt (1998) conducted an extensive analysis for different commodities - including soybean and corn, for the period between 1966 and 1995, validating the hypothesis of market efficiency in all cases on the CBOT.

The literature available on the Argentine market is much scarcer. The work of Delgado and Lema (2001) discovered the existence of a cointegrating relationship in the wheat futures market of Buenos Aires between 1995 and 2000. On the other hand, Grignafini (1998) reached the same conclusions for the futures market of soybean, corn and wheat crops in the city of Rosario. At the same time, Lachman (2016) highlights the efficiency of the futures market in Buenos Aires in the case of soybean, considering three different time lags between the future contracts and the spot price.

As was previously said, there are few studies that had made their focus on understanding small futures market and in the interaction between different markets. Maynard et al (2001) studied the behavior of future shrimp contracts traded at the Minneapolis Grain Exchange, which has a relatively low volume of trades, using weekly data between November 1994 and June 1998. In this article, the authors based their analysis in two contracts traded at the futures market and thirteen varieties of shrimps from the spot market. They found only one long run relationship between a contract from futures market and a particular variety of shrimp from the spot market. In contrast, all the other prices of shrimp varieties from the spot market failed to be cointegrated with any of the prices from the futures market. 
Finally, Malliaris and Urrutia (1998) conducted a complete literature review on the relationship between trade volume carried out in futures markets and prices. Using empirical data from the Chicago Board of Trade for corn, wheat, oats, soybean, soybean meal and soybean oil they studied the long run relationship between volumes traded and market efficiency. They showed a positive relationship between the absolute value of changes in price and the absolute volume traded in the Chicago market for the six commodities.

\section{METHODOLOGY}

Following the analysis of Fama (1991) and Mckenzie and Holt (2002), if we were to consider the existence of a constant arbitration between the operators of futures markets and a behavior of neutrality toward risk, the actual cost of a futures contract will be equal to the expected future price at the moment of the end of the said contract. Thus, the equation would be the following:

$$
F_{t-1}=E_{t-1} S_{t}
$$

$F_{t-1}$ being the price of futures contracts operated in the past, and $S_{t}$ being the current price of spot transactions.

Therefore, on the right side of this equation we have the expected value as $t-1$ of the spot price in $t$, which is equal to the price of futures contracts in $t-1$. In turn, if it is further assumed that agents have rational expectations, in such a way that they incorporate all available information each time they make a decision, then:

$$
E_{t-1}\left(S_{t} / \varphi_{t-1}\right)+\mu_{t}=S_{t}
$$

With $\varphi_{t-1}$ being the available information in $t-1$ and where $\mu_{t}$ represents the exogenous white noise term to all elements of $\varphi_{t-1}$. In this way, the previous equation can be rewritten as follows:

$$
\alpha+\beta F_{t-1}+\mu_{t}=S_{t}
$$

If the agents were always at neutral risk2 the last equation would constitute an identity with $\mathrm{F}_{\mathrm{t}-1}=\mathrm{S}_{\mathrm{t}}$, in such a way that $\alpha=0$ and $\beta=1$. If this were to

2 It should be noted that the equality that represents the risk neutral agents is not an assumption for this work. Along the same coefficient value $\alpha$ can be both positive and negative. 
happen in a particular futures market, it could be argued that agents can perfectly predict the future spot price based on futures contracts available today.

In order to be able to measure this, we will use the Johansen methodology (1995). This requires building a model of vector autoregression (VAR). This implies a statistical relationship where the variables are explained by lags of themselves and of the other variables. These can be represented as follows for each country and for each crop:

$$
\begin{gathered}
S_{t}=\alpha_{1}+\sum_{i=1}^{j} \beta_{1, i} F_{t-1-i}+\sum_{i=1}^{j} \gamma_{1, i} S_{t-i}+\mu_{t} \\
F_{t-1}=\alpha_{2}+\sum_{i=1}^{j} \beta_{2, i} F_{t-1-i}+\sum_{i=1}^{j} \gamma_{2, i} S_{t-i}+\mu_{t}
\end{gathered}
$$

With $\mathrm{j}=$ optimal amount of lags

VEC models are a type of VAR model that have variables capable to be cointegrated. Therefore, it is possible to establish a stationary vector, which results from a linear combination of nonstationary variables constituting the VAR. The long-term relationship these variables have with each other, which can be seen in the error correction term of the VEC, must take the following form for each country and for each crop:

$$
S_{t}=\alpha+\beta F_{t-1}+\varepsilon_{t}
$$

We must recall that the coefficient $\alpha$ represents, in this case, the risk premium to which operators of the future market face, while $\beta$ is going to signal the efficient levels of the future forecast. Therefore, $\beta<1$ will be overestimating the future spot price, whereas $\beta>1$ will be underestimating it. Should $\beta=1$, futures contracts would perfectly anticipate the spot price.

To corroborate the second working hypothesis, a VEC will be built for each crop where the long-term relationship is analyzed and it is as follows:

$$
F_{t ; A R G}=\alpha+\beta \quad F_{t ; U S A}+v_{t}
$$


In this case, represents the futures contracts for the Argentine market while represents the futures contract for the Chicago market. If a cointegrating relationship does exist, and the coefficient is statistically significant, we will be able to say that there is a transfer of information between markets. Additionally, we will proceed to do a weak exogeneity test to see which market has more influence over the other.

\section{I. Data}

For this research, we have considered daily information for the time period between 1994 and 2015, provided by MatBa (futures market of Buenos Aires) and the CMA-CBOT (futures market of Chicago). The data have been be retrieved from the corresponding websites of both grain stock markets3. Two contracts have been used for each year for both markets: May and November. Meanwhile, the spot price corresponds to the average contract expiration day of the month.

We use monthly average data to test individual market efficiency in each market and we use monthly average data and daily data to test the information transmission between markets4.

Finally, all values were transformed into logarithms, as is usually done in the literature.

\section{II.II. Unit root test}

Given that in order to construct a VEC model it is first necessary to know the amount of unit roots in each one of the series, the corresponding Augmented Dickey-Fuller test was performed for each one. This test was performed under the Schwartz criteria and with 10 maximum lags. Once proved that the series in levels were not stationary, the test was repeated in each case, but now considering the series with a first difference. The results obtained are summarized in the table 1 .

3 For the case of CMA-CBOT the data was provided by Reuters

4 At first stages of the work we had only used monthly average data for our research. But as we received comments that information is transmitted in a daily basis and not monthly basis, we decided to include a second analysis by using daily data to test the second hypothesis. In this article we show both results. 
CIENCIAS DEL COMPORTAMIENTO Y POLÍTICA: TIEMPO DE “EMPUJAR” LA CONDUCTA...

Table I. Augmented Dickey-Fuller Test of Stationaity

\begin{tabular}{|c|c|c|c|c|c|}
\hline \multirow[b]{2}{*}{ Variable } & \multicolumn{2}{|c|}{ Level } & \multicolumn{2}{|c|}{ First Difference } & \\
\hline & t stat & Prob.* & t stat & Prob.* & \\
\hline Arg_soybean_1 month & -2.203454 & 0.4754 & -6.790961 & 0.0000 & $\mathrm{I}(1)$ \\
\hline Arg_soybean_3 month & -2.237440 & 0.4574 & -7.358538 & 0.0000 & $\mathrm{I}(1)$ \\
\hline Arg_soybean_ 5 month & -2.613671 & 0.2766 & -9.007198 & 0.0000 & $\mathrm{I}(1)$ \\
\hline Arg_soybean_Spot & -2.858398 & 0.1859 & -7.904291 & 0.0000 & $\mathrm{I}(1)$ \\
\hline USA_soybean_1 month & -2.296405 & 0.4266 & -7.624029 & 0.0000 & $\mathrm{I}(1)$ \\
\hline USA_soybean_3 month & -2.262407 & 0.4443 & -7.308303 & 0.0000 & $\mathrm{I}(1)$ \\
\hline USA_soybean_ 5 month & -2.412557 & 0.3681 & -7.209227 & 0.0000 & $\mathrm{I}(1)$ \\
\hline USA_soybean_Spot & -2.305729 & 0.4218 & -7.756206 & 0.0000 & $\mathrm{I}(1)$ \\
\hline Arg_may_2005 & -1.497 .264 & 0.8259 & -1.046 .195 & 0.0000 & $\mathrm{I}(1)$ \\
\hline Arg_may_2006 & -1.906 .788 & 0.6452 & -1.079 .266 & 0.0000 & $\mathrm{I}(1)$ \\
\hline Arg_may_2012 & $-2,81409$ & 0,1951 & -1.045 .345 & 0,0000 & $\mathrm{I}(1)$ \\
\hline Arg_november_2005 & -2.368 .122 & 0.3945 & -1.245 .044 & 0.0000 & $\mathrm{I}(1)$ \\
\hline Arg_november_2006 & -0.117591 & 0.9941 & -1.162 .531 & 0.0000 & $\mathrm{I}(1)$ \\
\hline Arg_november_2012 & $-0,83804$ & 0,9587 & -1.063 .443 & 0,0000 & $\mathrm{I}(1)$ \\
\hline USA_may_2005 & -1.478 .936 & 0.8321 & -1.005 .869 & 0.0000 & $\mathrm{I}(1)$ \\
\hline USA_may_2006 & -2.752 .463 & 0.2179 & -8.979 .331 & 0.0000 & $\mathrm{I}(1)$ \\
\hline USA_may_2012 & $-2,66978$ & 0,2510 & -1.114 .948 & 0,0000 & $\mathrm{I}(1)$ \\
\hline USA_november_2005 & -2.174 .215 & 0.4996 & -1.221 .106 & 0.0000 & $\mathrm{I}(1)$ \\
\hline USA_november_2006 & -0.172447 & 0.9931 & -1.194 .088 & 0.0000 & $\mathrm{I}(1)$ \\
\hline USA_november_2012 & $-0,43331$ & 0,9854 & -1.088 .565 & 0,0000 & $\mathrm{I}(1)$ \\
\hline
\end{tabular}

Note: At the level series for soybean and wheat the test was made with intercept and trend. For the first difference series form soybean and wheat, the test was made with none intercept and trend.

Source: Author's own elaboration. 
This test has a null hypothesis that the variables have a unit root (i.e. they are not stationary), so we can see that at a significant level of $5 \%$, all of the series are I(1). Therefore, it can be said that the series are stationary in their first difference.

\section{RESULTS FOR EFFICIENCY MARKET STUDY}

Based on literature previously mentioned, the construction of an error correction vector will permit the testing of the market efficiency hypothesis for the case of MatBa and CME-CBOT within the selected period. If the series corresponding to the spot prices and the futures contracts for the three selected periods are not firstorder stationary and the VAR model meets the three requirements for the respective errors - normality, not autocorrelation and homoscedasticity - , it is possible to assess the existence of cointegration for each of the armed models.

Since, in the previous section, it was demonstrated that all of the series are I(1) and that the required conditions of waste VAR models are fulfilled5, cointegration tests were performed and the coefficients of the VEC models were estimated.

\section{III.I. Cointegration test results}

From a VAR model, having verified the consistency in its estimation through the waste tests, it is possible to estimate a VEC if a cointegration relationship between the VAR variables is found. The Johansen test was used to detect the long-term relationship between variables. In turn, since the data has a consistent trend and intercept, these aspects should be taken into account when selecting the criteria for the Johansen test6. In addition, since all of the series used in this paper are I(1), a single cointegration relationship was sought between them.

Table 2 show the test results mentioned for individually market efficiency for the three constructed models: with contracts lagged one month, three months and five months from their expiration date.

5 The corresponding results to the tests performed to the VAR models can be found in the annex of this report.

$6 \quad$ For this paper, the criteria defined by the software is used on all models as: "linear deterministic trend in data and intercept (no trend) in CE and VAR test”. 
Table 2. Johansen cointegration test results for futures contracts and spot price

\begin{tabular}{|c|c|c|c|c|c|}
\hline & \multicolumn{4}{|c|}{ Soybean - Monthly data } & \\
\hline & \multicolumn{2}{|c|}{$\lambda_{\text {trace }}$} & \multicolumn{2}{|c|}{$\lambda_{\max }$} & \\
\hline & H0: & H0: & H0: & H0: & \\
\hline Model & $\mathrm{r}=0$ & $\mathrm{r} \leq 1$ & $\mathrm{r}=0$ & $\mathrm{r} \leq 1$ & \\
\hline MatBa 1 month & 24.85680 & 2.273786 & 22.58302 & 2.273786 & \multirow{2}{*}{ cointegrated } \\
\hline $\mathrm{p}$-value & 0.0015 & 0.1316 & 0.0020 & 0.1316 & \\
\hline MatBa 3 months & 35.40444 & 1.455195 & 33.94925 & 1.455195 & \multirow{2}{*}{ cointegrated } \\
\hline p-value & 0.0000 & 0.2277 & 0.0000 & 0.2277 & \\
\hline MatBa 5 months & 40.08220 & 1.459776 & 38.62242 & 1.459776 & \multirow{2}{*}{ cointegrated } \\
\hline p-value & 0.0000 & 0.2270 & 0.0000 & 0.2270 & \\
\hline CME-CBOT 1 month & 34.03905 & 3.335877 & 30.70317 & 3.335877 & \multirow{2}{*}{ cointegrated } \\
\hline p-value & 0.0000 & 0.0678 & 0.0001 & 0.0678 & \\
\hline CME-CBOT 3 months & 52.11550 & 2.674029 & 49.44147 & 2.674029 & \multirow{2}{*}{ cointegrated } \\
\hline p-value & 0.0000 & 0.1020 & 0.0000 & 0.1020 & \\
\hline CME-CBOT 5 months & 70.61452 & 2.206355 & 68.40817 & 2.206355 & \multirow{2}{*}{ cointegrated } \\
\hline p-value & 0.0000 & 0.1374 & 0.0000 & 0.1374 & \\
\hline
\end{tabular}

Note: In all the cases it was used the test for "Linear Trend and with Intecept No Trend".

Source: Author's own elaboration.

As indicated in the results from table 2, through the maximum likelihood method, or by the trace method, all models presented a unique cointegration relationship.

By verifying the cointegration relationship between the series for each one of the models, we can say — given the hypothesis of this paper - that in all cases the markets behaved in efficient conditions for the selected time period. In this way, prices from futures market worked as a forecast for the spot prices.

III.II. VEC coefficients and long-term relationship

Since each one of the VEC models constructed in this paper for the purpose of studying market efficiency show the long-term relationship that exists between the variables considered, it is relevant to elaborate on the continuation of the value 
and sign of the coefficients obtained for each case7. The values of the coefficients obtained from the estimated models are presented in table 3.

Table 3. VEC models for individual market efficiency

\begin{tabular}{rcc} 
& \multicolumn{2}{c}{ Soybean } \\
\cline { 2 - 3 } Model & $\alpha$ & $\beta$ \\
\hline \multicolumn{1}{c}{ MatBa 1 month } & -0.203534 & 1.036 .357 \\
p-value & & $(0.02329)$ \\
\hline MatBa 3 months & 0.035645 & 0.996854 \\
p-value & & $(0.02481)$ \\
\hline MatBa 5 months & $-0.216454^{*}$ & $1.043048^{*}$ \\
p-value & & $(0.02483)$ \\
\hline CME-CBOT 1 month & 0.104972 & 0.984656 \\
p-value & & $(0.01479)$ \\
\hline CME-CBOT 3 months & 0.191979 & 0.970479 \\
p-value & & $(0.03212)$ \\
\hline CME-CBOT 5 months & -0.076488 & 1.017 .350 \\
& & $(0.03550)$ \\
\hline
\end{tabular}

Note: in all the cases is proved weak exogenity from the spot variable but not in * Source: Author's own elaboration.

First, it can be noted that in all models, the coefficient " $\alpha$ " - assumed as the time-varying risk premium - is negative and is also growing (in absolute terms) as we consider time periods more distant from the moment of implementation of the futures contract.

This is intuitively consistent given that as we negotiate any given futures contract that is far from implementation, it will have to assume a larger risk pre-

7 It's worth noting that these models were established as stable and their coefficients significant. To evaluate the significance of the coefficients obtained, we proceeded to perform a test imposing restrictions, so as to see if these restrictions would break, or not, the cointegration relationship. Therefore, the coefficients were forced to be equal to zero, so that if the cointegration relationship maintained valid, then said coefficient was not significant as it did not provide relevant information. 
mium because its uncertainty increases. At the same time, the negative sign of the coefficient " $\alpha$ " responds to the fact that there is an inherent risk to the prices negotiated in advance of the distribution of goods. This can be affected by multiple exogenous shocks. It may happen that producers tend to agree on, in statistical terms, the values of the futures contracts. This is what happened in the period analyzed in this paper.

On the other hand, in all cases, the coefficient " $\beta$ " is positive and close to one, which, in turn, also tends to increase - in the majority of cases — as we consider contracts further away from their implementation period. This result is also intuitively expected, because as we consider contracts with a greater time lag with respect to the future spot price, the possibility of erring more on the expected price increases. Therefore, statistically, underestimation of the expected future price spot is higher as we move further away in time.

\section{RESULTS FOR INFORMATION TRANSMISSION BETWEEN MARKETS}

Following the analysis proposed in this paper, the results obtained for the testing of the second hypothesis will be presented next. To that effect, we analyzed the existence of cointegration between prices from Matba and CME-CBOT, for each one of the estimated VARs, and VEC models continued to be built for each VAR (equation number 7)8. We estimated three models using monthly data for different lag periods - one month, three month and five month - , and also we include in this article six more models based in daily data and with six month lag9.

Finally, for these VEC models, the weak exogeneity test was performed in order to evaluate which market has more influence over the other. The latter led to the conclusion about the direction in which information travels between the two selected markets.

\footnotetext{
8 The corresponding results to the waste tests performed to the VAR models can be found in the annex of this paper.

9 For these estimated models with daily data we used the contracts from May 2005, 2006, 2012 and from November 2005, 2006 and 2012 based on the availability of information for both markets.
} 


\section{IV.I. Cointegration test results}

As was done in the previous section, having verified the consistency in estimating VARs through waste tests, the Johansen test (1991 and 1995) was used to verify if a cointegration relationship exists between the variables10.

Table 4 shows the results of the test mentioned that relates both markets based on the constructed models with monthly data - for contracts lagged one month, three months and five months from their expiration date - and the ones estimated by using daily data — and with six month lagged.

As obtained in the previous section, the results indicate that both set of models, through the maximum likelihood method, or by the trace method, presented one cointegration relationship.

In this case, by getting cointegration relationship between the futures markets of Chicago and Buenos Aires for the commodity selected, we can say — given the first part of the second hypothesis of this paper - that a long-term relationship exists between the two said markets in all cases studied. The long run relationship persists by using monthly data and also with daily data.

\section{IV.II. VEC coefficients and weak exogeneity test between markets}

Having demonstrated the existence of a long-term link between the futures markets of Buenos Aires and Chicago for both set of models through the presence of a cointegration relationship between them, it is now possible to analyze whether Chicago indeed has a greater market influence over the Buenos Aires market, as suggested in the second hypothesis of this paper. For this, the corresponding associated VEC models are estimated for each model, and, in each case, it is tested if the number of futures contracts of CME-CBOT is weakly exogenous. The results obtained for the estimation are presented in table $5^{11}$.

\footnotetext{
10 The criteria defined by the software used was utilized in all models as: "linear deterministic trend in data and intercept (no trend) in CE and VAR test”, since the data has a constant trend and intercept. Additionally, since the series used are I(1), it seeks to obtain a single cointegration relationship between them.

11 For these models, it was verified that they are stable and their coefficients significant, as was done in the previous section.
} 
Table 4. Johansen cointegration test results between Matba and CME-CBOT

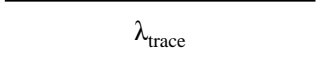

\begin{tabular}{rr}
\hline H0: & H0: \\
\hline$r=0$ & $r \leq 1$
\end{tabular}

\begin{tabular}{lc}
\hline \multicolumn{2}{c}{$\lambda_{\max }$} \\
\hline $\mathrm{H} 0:$ & $\mathrm{H} 0:$ \\
\hline $\mathrm{r}=0$ & $\mathrm{r} \leq 1$
\end{tabular}

Soybean - Monthly data

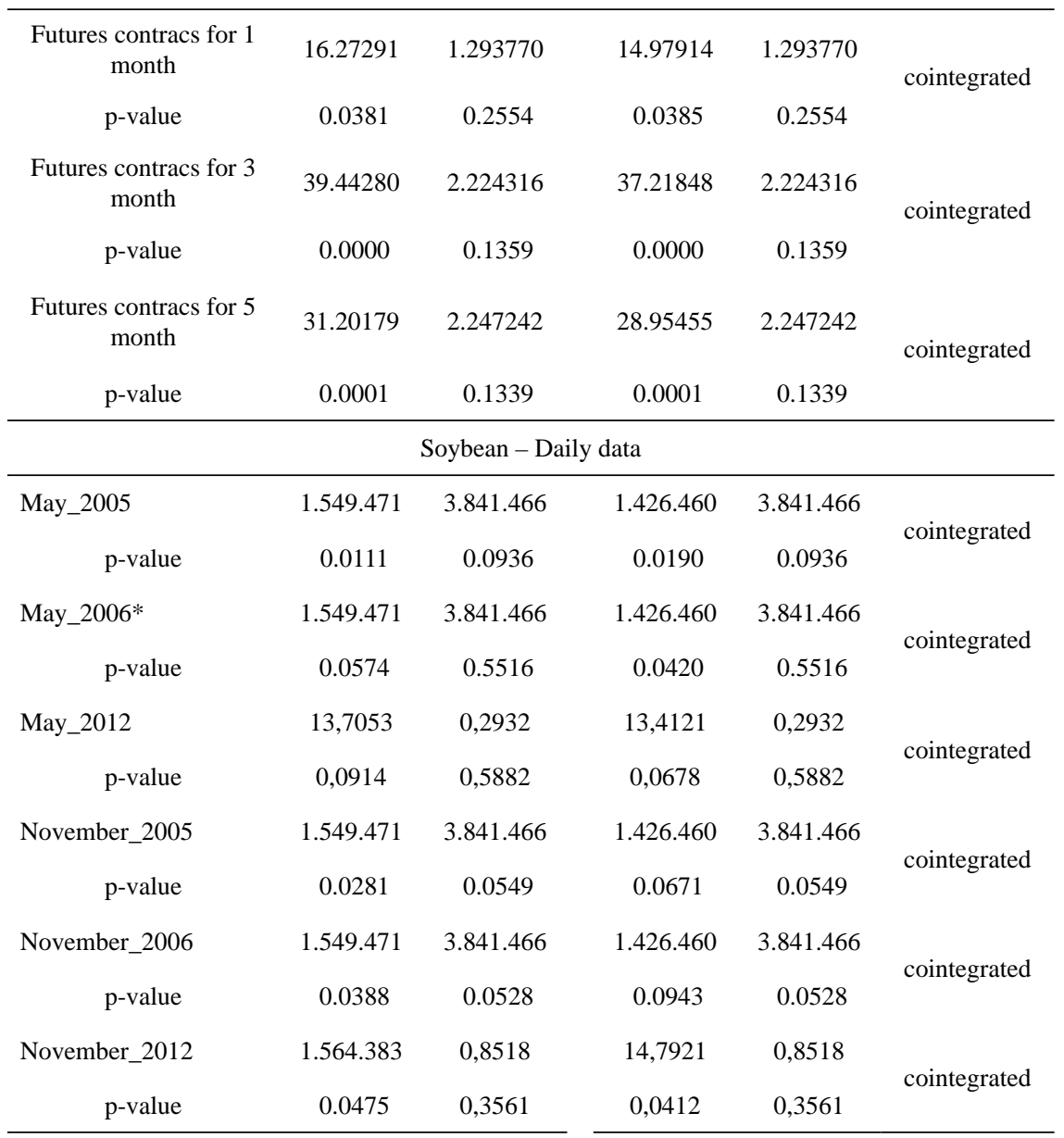

Note: In all the cases it was used the test for "Linear Trend and with Intecept No Trend"; * means that the model was lagged for a three month.

Source: Author's own elaboration. 
Table 5. VEC models for information transmition

\begin{tabular}{|c|c|c|c|}
\hline Model & $\alpha$ & $\beta$ & Weak exogenity variable \\
\hline \multicolumn{4}{|c|}{ Soybean - Monthly data } \\
\hline Futures contracs for 1 month & 0.772698 & 0.856890 & CME-CBOT futures contrac \\
\hline p-value & & $(0.02896)$ & \\
\hline Futures contracs for 3 month & 0.704243 & 0.867871 & CME-CBOT futures contrac \\
\hline p-value & & $(0.02560)$ & \\
\hline Futures contracs for 5 month & 0.860947 & 0.839144 & CME-CBOT futures contrac \\
\hline p-value & & (0.03389) & \\
\hline \multicolumn{4}{|c|}{ Soybean - Daily data } \\
\hline May_2005 & 0.019040 & 0.973757 & CME-CBOT futures contratc \\
\hline p-value & & $(0.02197)$ & \\
\hline May_2006a & -0.618961 & 1257082 & CME-CBOT futures contrac \\
\hline p-value & & $(0.24455)$ & \\
\hline May_2012 & 0.104912 & 0.942377 & CME-CBOT futures contrac \\
\hline p-value & & $(0.03457)$ & \\
\hline November_2005b & -0.014500 & 1000000 & CME-CBOT futures contrac \\
\hline \multicolumn{4}{|l|}{ p-value } \\
\hline November_2006 & 1698742 & 0.274973 & CME-CBOT futures contrac \\
\hline p-value & & $(0.08592)$ & \\
\hline November_2012 & 1.439.976 & 0.468959 & CME-CBOT futures contrac \\
\hline p-value & & $(0.11625)$ & \\
\hline
\end{tabular}

Note: "a" means that the model was lagged for three month; "b" indicates that $\beta$ was forced to be equal to one. Source: Author's own elaboration.

Given that the coefficient " $\beta$ " is statistically significant, it can be said that there is a transfer of information between the two markets. 
Additionally, for both set of models, the futures contracts from the Chicago Board of Trade proved to be weakly exogenous. From these strong results, we can show that the Chicago futures market influence the prices behavior of the Buenos Aires futures market, at least for the soybean crop, and this is because information is transmitted from one market to the other.12

\section{CONCLUSION}

In the first section of this paper, the efficiency of the futures markets in the case of soybean in the MatBa and the CME-CBOT were analyzed. The results obtained show that, throughout the period covered, both markets operated under efficient conditions. Thus, the prices of the mentioned commodity obtained from futures markets operated, in statistical terms, as a forecast of spot prices. This was confirmed, having found a cointegration relationship with either one, three, and five months lag. At the same time, the coefficients of the VEC models provided additional information about the way in which the variables are related in the long run.

In the second section of this paper, we showed that there is an important relationship between the efficiency of the Chicago futures market and the Buenos Aires futures market, for both set of models. As we found a cointegration relationship between all of the estimated models, we can conclude that there is a long-term relationship between the contracts from both futures markets.

Finaly, the results reached also show that changes in the prices of CMECBOT influence changes in the MatBa prices. This was demonstrated by the existence of weak exogeneity in the error correction model by the Chicago futures market for all cases analyzed. Since this relationship can be demonstrated in all models, it can be concluded that this influence proved to be highly relevant to the efficient operation of the Buenos Aires futures market. In this way, despite the relatively low operational volume carried out by the MatBa, the futures market could operate in efficient conditions thanks to the transfer of information from the CME-CBOT.

12 In this case, the coefficient " $\alpha$ " - assumed as the time-varying risk premium for the efficiency analysis of the market of the previous section -, will represent the risk premium associated with the Buenos Aires market. Certainly, its interpretation lacks relevance for the purposes of the objectives of this paper. 


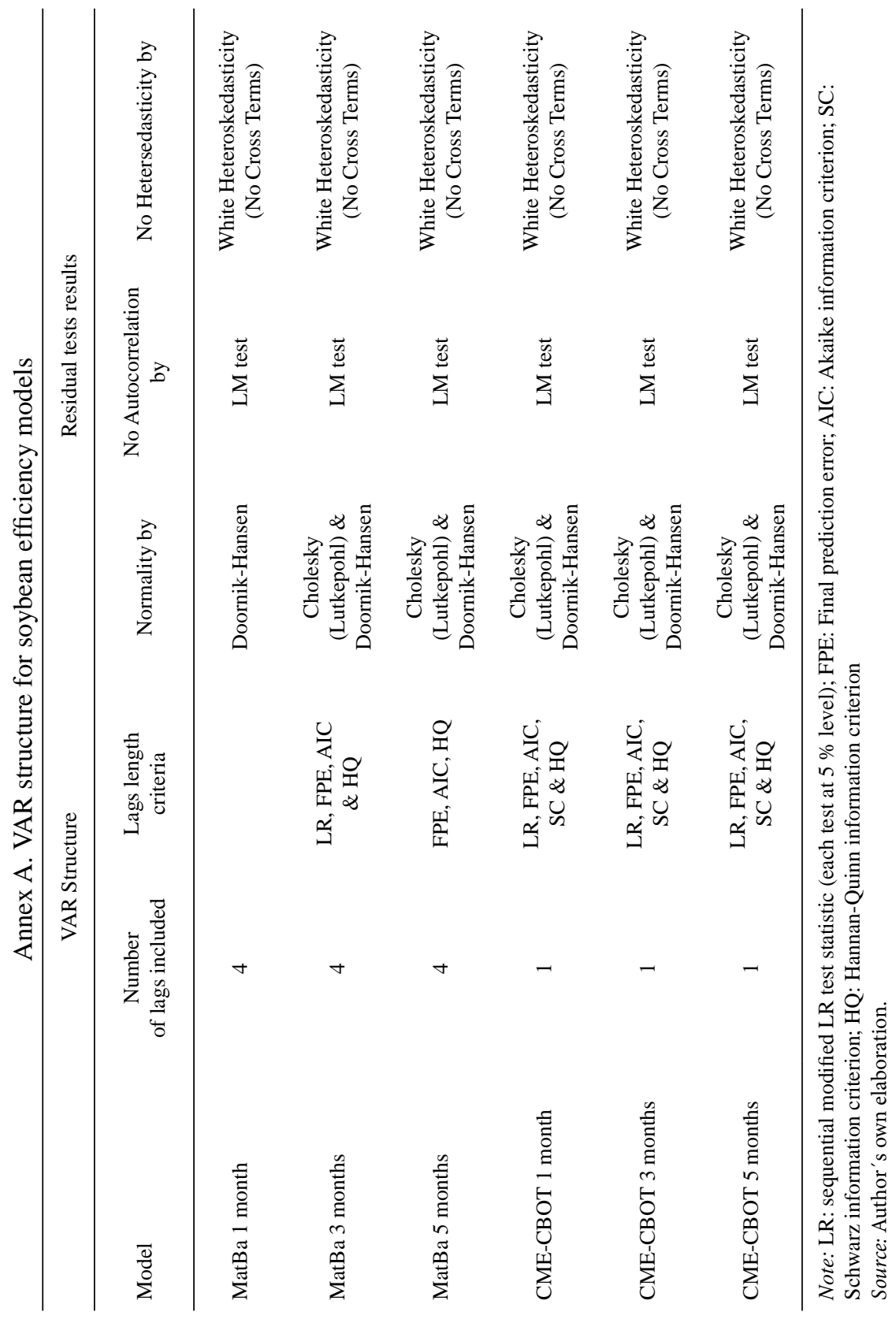


Annex B. VAR structure for the information transmission between markets models

\begin{tabular}{|c|c|c|c|c|c|}
\hline & \multicolumn{2}{|c|}{ VAR Structure } & \multicolumn{3}{|c|}{ Residual tests results } \\
\hline Model & $\begin{array}{l}\text { Number } \\
\text { of lags } \\
\text { included }\end{array}$ & $\begin{array}{l}\text { Lags length } \\
\text { criteria }\end{array}$ & $\begin{array}{l}\text { Normality } \\
\text { by }\end{array}$ & $\begin{array}{c}\text { No } \\
\text { Autocorrelation } \\
\text { by }\end{array}$ & $\begin{array}{c}\text { No } \\
\text { Heteroskedasticity } \\
\text { by }\end{array}$ \\
\hline $\begin{array}{l}\text { Futures contracs } \\
\text { for } 1 \text { month }\end{array}$ & 5 & LR & $\begin{array}{c}\text { Doornik- } \\
\text { Hansen }\end{array}$ & LM test & $\begin{array}{l}\text { White } \\
\text { Heteroskedasticity } \\
\text { (No Cross Terms) }\end{array}$ \\
\hline $\begin{array}{l}\text { Futures contracs } \\
\text { for } 3 \text { months* }\end{array}$ & 1 & $\begin{array}{l}\text { FPE, AIC, } \\
\text { SC \& HQ }\end{array}$ & $\begin{array}{c}\text { Doornik- } \\
\text { Hansen }\end{array}$ & LM test & $\begin{array}{l}\text { White } \\
\text { Heteroskedasticity } \\
\text { (No Cross Terms) }\end{array}$ \\
\hline $\begin{array}{l}\text { Futures contracs } \\
\text { for } 5 \text { month }\end{array}$ & 1 & $\begin{array}{l}\text { LR, FPE, } \\
\text { AIC, SC \& } \\
\text { HQ }\end{array}$ & $\begin{array}{l}\text { Cholesky } \\
\text { (Lutkepohl) } \\
\text { \& Doornik- } \\
\text { Hansen }\end{array}$ & LM test & $\begin{array}{l}\text { White } \\
\text { Heteroskedasticity } \\
\text { (No Cross Terms) }\end{array}$ \\
\hline May_2005 & 5 & LR & $\begin{array}{l}\text { Cholesky } \\
\text { (Lutkepohl) } \\
\text { \& Doornik- } \\
\text { Hansen }\end{array}$ & Test LM & $\begin{array}{l}\text { White } \\
\text { Heteroskedasticity } \\
\text { (No Cross Terms) }\end{array}$ \\
\hline May_2006* & 4 & & $\begin{array}{l}\text { Cholesky } \\
\text { (Lutkepohl) } \\
\text { \& Doornik- } \\
\text { Hansen }\end{array}$ & Test LM & $\begin{array}{l}\text { White } \\
\text { Heteroskedasticity } \\
\text { (No Cross Terms) }\end{array}$ \\
\hline May_2012 & 18 & & $\begin{array}{l}\text { Doornik- } \\
\text { Hansen }\end{array}$ & Test LM & $\begin{array}{c}\text { White } \\
\text { Heteroskedasticity } \\
\text { (No Cross Terms) }\end{array}$ \\
\hline November_2005 & 13 & & $\begin{array}{l}\text { Cholesky } \\
\text { (Lutkepohl) } \\
\text { \& Doornik- } \\
\text { Hansen }\end{array}$ & Test LM & $\begin{array}{l}\text { White } \\
\text { Heteroskedasticity } \\
\text { (No Cross Terms) }\end{array}$ \\
\hline November_2006 & 14 & & $\begin{array}{l}\text { Cholesky } \\
\text { (Lutkepohl) } \\
\text { \& Doornik- } \\
\text { Hansen }\end{array}$ & Test LM & $\begin{array}{l}\text { White } \\
\text { Heteroskedasticity } \\
\text { (No Cross Terms) }\end{array}$ \\
\hline November_2012 & 16 & & $\begin{array}{c}\text { Doornik- } \\
\text { Hansen }\end{array}$ & Test LM & $\begin{array}{l}\text { White } \\
\text { Heteroskedasticity } \\
\text { (No Cross Terms) }\end{array}$ \\
\hline
\end{tabular}

Note: LR: sequential modified LR test statistic (each test at $5 \%$ level); FPE: Final prediction error; AIC: Akaike information criterion; SC: Schwarz information criterion; HQ: Hannan-Quinn information criterion Source: Author's own elaboration. 


\section{BIBLIOGRAPHY}

Ali, J., \& Grupta, K. B. (2011). Efficiency in agricultural commodity futures markets in India: Evidence from cointegration and causality tests. Agricultural Finance Review, 71 (2), 162-17.

Armah, P., \& Shanmugamb, V. (2013). Price Hikes in US Agricultural Commodity Futures Markets: An Empirical Efficiency Test. Journal of Food Distribution Research, 44 (1), 66-77.

Arouri, M., Jawadi, F., \& Mouak, P. (2011). The Speculative Efficiency of the Aluminum Market: A Nonlinear Investigation. International Economics, 126-127, 73-89.

Beck, E. S. (1994). Cointegration and Market Efficiency in Commodities Futures Markets. Applied Economics, 26 (3), 249-257.

Carter, C. A. (1989). Arbitrage opportunities between thin and liquid futures markets. The Journal of Futures Markets, 9 (4), 347-353.

Delgado, G., \& Lema, D. (2001). Eficiencia en el Mercado de Commidities Agrícolas: La Paridad entre Precio Spot y Futuro de Trigo en Argentina 19952000. Rosario, Argentina: AAEA.

Enders, W. (2015). Applied Econometrics Time Serie. New York: Wiley.

Fama, E. F. (1970). Efficient capital markets: A review of theory and empirical work. Journal of Finance, 25 (2), 383-417.

Fama, E. F. (1991). Efficient capital markets: II. Journal of Finance, 46 (5), 1575-1617.

Fama, E. F., \& French, K. (1987). Commodity futures prices: Some evidence of forecast power premiums and the theory of storage. Journal of Business, 60 (1), 55-73.

Fisanotti, L. (2014). Antecedentes Históricos de los Mercados de Futuros y Opciones: Cobertura y Especulación. INVENIO, 17 (33), 9-19.

Grignafini, A. (2000). La eficiencia en los mercados de futuros : análisis empírico del mercado rosarino. En Bolsa de Comercio de Rosario, Lecturas N. 3 (pp. 55-94). Rosario: Ediciones Capacitación \& Desarrollo de Mercados.

Hull, J. (2012). Options, Futures, and Other Derivatives Securities. Boston: Prentice Hall.

Johansen, S. (1995). Likelihood-based Inference in Cointegrated Vector Auto-regressive Models. Oxford: Oxford University Press.

Kumar, S., \& Sunil, B. (2004). Price Discovery and Market Efficiency: Evidence from Agricultural Commodities Futures Markets. South Asian. Journal of Management, 11 (2).

Lachman, J. (2016). Estudio sobre la Eficiencia y la Previsión Perfecta en el Mercado de Futuros Agrícolas: un Análisis para el MatBa en el Caso Particular del Cultivo de Soja entre 2005 y 2014. Recuperado de https://issuu. 
com/jeremiaslachman/docs/lachman_estudio_sobre_la_eficiencia?workerAddress=ec2-54-174-194-75.compute-1.amazonaws.com

Malliaris, A. G., \& Urrutia, J. L. (1998). Volume and Price Relationships: Hypotheses and Testing for Agriculture Futures. The Journal of Futures Markets, 18 (1), 53-72. Recuperado de http://onlinelibrary.wiley.com/doi/10.1002/ (SICI)1096-9934(199802)18:1\%3C53::AID-FUT3\%3E3.0.CO;2-A/epdf

Maynard, L. J., Hancock, S., \& Hoagland, H. (2001). Performance of shrimp futures markets as price discovery and hedging mechanisms. Agriculture Economics and Management, 5 (3-4), 115-128.

Mackenzi, A., \& Holt, M. (2002). Market efficiency in Agricultural Futures Markets. Applied Economics, 34 (12), 1519-1532.

Wang, H. H., \& Ke, B. (2005). Efficiency tests of agricultural commodity futures markets in Cihina. Australian Journal of Agricultural and Resources Economics, 42 (2), 125-141.

Watkins, C., \& McAleer, M. (2006). Pricing of Non-Ferrous Metals Futures on the London Metal Exchange. Applied Financial Economics, 16 (12), 853-880.

Yang, J., Bessler, D. A., \& Leatham, D. J. (2001). Asset storability and price discovery in commodity futures markets: a new look. The Journal of Futures Markets, 21 (3), 279-300.

(C) 2017 por los autores; licencia otorgada a la revista Estudios económicos. Este artículo es de acceso abierto y distribuido bajo los términos y condiciones de una licencia Atribución-No Comercial 3.0 Unported (CC BY-NC 3.0) de Creative Commons. Para ver una copia de esta licencia, visite http://creativecommons.org/ licenses/by-nc/3.0/ 